\title{
Correlation of umbilical cord blood volume with CD34+ cells concentration
}

\author{
Tulika Chandra, Sheeba Afreen, Ashutosh Kumar, Uma Singh
}

\begin{abstract}
Aims: Umbilical cord blood (UCB) has been recently considered as an alternative source of hematopoitic progenitor cells for clinical application. The parameters commonly used to evaluate a UCB unit and predict transplant outcomes have been total nucleated cell count (TNCs), CD34+ cells concentration and total volume of cord blood collected. The volume of cord blood collection is also important for the high yield of $\mathrm{CD}_{34}+$ cells concentration and TNCs. The aim of the study was to find the correlation of umbilical cord blood volume with cord blood derived CD34+ cells concentration. Methods: Umbilical cord blood was collected from normal vaginal and cesarean deliveries. Total volume of cord blood collection was noted. It was immediately processed and assessed for
\end{abstract}

Tulika Chandra ${ }^{1}$, Sheeba Afreen ${ }^{1,2}$, Ashutosh Kumar ${ }^{2}$, Uma Singh ${ }^{3}$

Affiliations: ${ }^{1}$ Department of Transfusion Medicine and Blood Bank, Chhatrapati Shahuji Maharaj Medical University (Earlier King Georg's Medical University), Lucknow Uttar Pradesh, India; ${ }^{2}$ Professor, Department of Pathology, Chhatrapati Shahuji Maharaj Medical University (Earlier King Georg's Medical University), Lucknow Uttar Pradesh, India; ${ }^{3}$ Professor, Department of Obstetrics and Gynecology, Chhatrapati Shahuji Maharaj Medical University (Earlier King Georg's Medical University), Lucknow Uttar Pradesh, India.

Corresponding Author: Dr. Tulika Chandra, Assistant Professor, Department of Transfusion Medicine and Blood Bank, Chhatrapati Shahuji Maharaj Medical University, Lucknow, Uttar Pradesh, India; Ph: +919415755536; Email: tulikachandra@rediffmail.com

Received: 27 April 2011

Accepted: 09 August 2011

Published: 31 October 2011 total nucleated cells count and $\mathrm{CD}_{34}+$ cells concentration. Assessment of maternal and neonatal parameters such as mode of delivery, baby's birth weight and sex, cord blood volume and $\mathrm{CD}_{34+}+$ cells concentration was made. Results: Total volume of cord blood and CD34+ cells concentration positively correlated with cesarean delivery and higher birth weight of the baby $(\mathbf{p}<0.01)$. We also found that, CD34+ cells concentration was higher in greater volume of collected cord blood. Conclusions: Our study concludes that higher volume of cord blood should be preferred for processing and stem cell infusion.

Keywords: CD34+ cells, TNC, Cord blood volume, Stem cells

$$
* * * * * * * * *
$$

Chandra T, Afreen S, Kumar A, Singh U. Correlation of umbilical cord blood volume with $\mathrm{CD}_{34+}+$ cells concentration. International Journal of Blood Transfusion and Immunohematology 2011;1:12-16.

Article ID: 100003IJBTITC2011.

$$
* * * * * * * * *
$$

doi:10.5348/ijbti-2011-3-OA-3

\section{INTRODUCTION}

Umbilical cord blood (UCB) contains hematopoitic stem/progenitor cells that have proven useful clinically to reconstitute the hematopoitic system in children and adults. This source of stem cells has been successfully used to replace bone marrow transplantation. Cord blood has several advantages over adult hematopoitic stem cell sources. These include ease and safety of 
procurement, rapid availability, no donor attrition, decreased viral transmission, unlimited supply, increased ethnic representation, abundance of hematopoitic progenitor cells, enhanced in vitro proliferative and self renewal capacity, immaturity of Tcell-mediated immunity, reduced graft versus host disease (GVHD) and diminished need of HLA matching [1-3]. Hence, for the first time in 1988, cord blood (CB) was used as an alternative source of HSCT in a child with Fanconi anemia [4] which had several benefits such as ability to tolerate HLA mismatched transplants $[5,6]$, a lower risk of acute and chronic GVHD [7, 8] and lower risk of blood-transmitted infectious diseases. It has been shown that cord blood contains sufficient progenitor cells to provide durable engraftment. As a response to the initial encouraging clinical results of cord blood transplants, several cord blood banks have been established worldwide [9]. Cord blood processing and cryopreservation is a very costly procedure. Cord blood units (CBU) require expensive storage in nitrogen tanks, but only a small percentage of them are used for transplantation. The parameters commonly used to evaluate a UCB unit and predict transplant outcomes have been total nucleated cell count (TNCs), CD $34+$ cells concentration and total volume of cord blood collected. The volume of cord blood collection is crucial for the yield of high number of TNC and CD $34+$ cells when the collection is performed for banking and transplantation reasons.

High cord blood nucleated and CD34+ cell counts as well as the number of haematopoitic progenitor cells (Colony forming cells) in the transplant are associated with good transplantation results [10]. In clinical application, the number of mononuclear cells and CD34+ cells infused have proved to be the major prognostic factor for faster engraftment and prolonged survival.

The aim of the present study is to find the correlation between umbilical cord blood volume and cord blood derived CD34+ cells concentration. This would help in reducing the cost for collection, transfer, storage and analysis of cord blood units (CBUs).

\section{MATERIALS AND METHODS}

Five hundred umbilical cord blood samples were obtained from both vaginal and cesarean deliveries from the Department of Obstetrics and Gynecology, CSMMU, Lucknow, India.

Informed consent was taken prior to the collection of cord blood. Women with known history of hepatitis, infectious disease, diabetes mellitus, severe hypertension, abortions or bad obstetrics history were excluded from the study. Only healthy pregnant adult woman without any complications were included. Cord blood was collected from 380 (76\%) normal vaginal and 120 (24\%) cesarean deliveries after the completion of delivery before placenta expulsion. After the delivery of the baby the cord was clamped and a needle was inserted into the umbilical vein above the clamp. The blood was drained via gravity into the sterile collection bag, containing Citrate Phosphate Dextrose Adenine (CPDA) as an anticoagulant.

Cord blood donor infants: Birth weight, sex of the baby, mode of delivery and gestational age of the baby were recorded. Infants delivered at term (31-41 wks) were included in our study. After collection, the cord blood was sent in the transport boxes to the Department of Transfusion Medicine, C.S.M.M.U, Lucknow.

Cord Blood Processing: Processing was done within 24 hours of cord blood collection. Aliquots of blood were used for routine testing, including cell counts, CD $34+$ cell concentration, and viability assay. Transmissible disease testing for Human Immunodeficiency Virus (HIV-2), Hepatitis B Surface Antigen (HBsAg), Hepatitis B virus (HBV) and hepatitis $\mathrm{C}$ Virus (HCV) and syphilis were also performed. The processing of samples, which included the determination of cord blood volumes, the determination of initial level of total nucleated cells (TNC) and mononuclear cells (MNC) before centrifugation was done. The UCB product was then mixed with hydroxyethyl starch in a 5:1 ratio and centrifuged at $1200 \mathrm{rpm}$ for $10 \mathrm{~min}$. The WBC-rich plasma was expressed in a separate bag and again centrifuged at $2500 \mathrm{rpm}$ for $10 \mathrm{~min}$. The WBC poor plasma was expressed and discarded. The remaining suspension of mononuclear cells was left whose counts were recorded. The UCB mononuclear cells were cryopreserved using the cryoprotectant solution containing 50\% DMSO in $5 \%$ (wt/vol) Dextran 40 at a final concentration of $10 \%$.

Laboratory Assays: The Total nucleated cell count was performed by automated cell counter (Sysmex KX21, Japan). The viability was tested with Trypan Blue; dye exclusion method. The CD34+ cells were performed by using flow cytometry analysis.

Statistics: Data were reported as means \pm standard deviation. Descriptive statistics were presented for each maternal and neonatal factor. The Pearson correlation test was used for analysis. The level of statistical significance was set at 0.01 two sided for Pearson correlation $(\mathrm{p}<0.01)$.

\section{RESULTS}

Total 500 UCB samples were analyzed. Amongst them according to their newborn sex distribution, 282 infants $(56.4 \%)$ were males and 218 (43.6\%) were females. The median gestational age was 38 wks (mean $37.57 \pm 1.82$ wks, range 31-41). The distribution of birth weight was normal (mean $2790 \pm 426$ gram, range $1800-$ 3900 , table 1). The median of mother's age was $28 \mathrm{yrs}$ (mean $28.47 \pm 4.26$, range 19-44 years). The mean of the total volume collection and total $\mathrm{CD}_{34}{ }^{+}$cells concentrations were $79.4713 .04 \mathrm{ml}$ (median 80, range $70-120 \mathrm{ml}$ ) and $0.41 \pm 0.42 \%$ (median 0.20 , range $0.02-$ $1.98 \%$ ) respectively in vaginal delivery. The mean of the total volume collection and $\mathrm{CD} 34+$ cells concentration were $137.22 \pm 17.80 \mathrm{ml}$ (range $100-160 \mathrm{ml}$ ) and $2.42 \pm$ 
Table 1: Characteristics of the study subjects by study site $(n=500)$.

\begin{tabular}{|c|c|}
\hline Characteristics & Mean \pm SD or $\mathbf{N}(\%)$ \\
\hline \multicolumn{2}{|l|}{ Newborn gender } \\
\hline Male & $282(56.4 \%)$ \\
\hline Female & $218(43.6 \%)$ \\
\hline Gestation Duration (weeks) & $37.57 \pm 1.82$ \\
\hline \multicolumn{2}{|l|}{ Birth weight } \\
\hline 1800-2500 gram & $168(33.6 \%)$ \\
\hline 2600-390o gram & $332(66.4 \%)$ \\
\hline \multicolumn{2}{|l|}{ Total UCB volume collection } \\
\hline $50-100$ & 180 \\
\hline $101-160$ & 320 \\
\hline Normal Vaginal Delivery & 173 \\
\hline Caesarian Delivery & 327 \\
\hline
\end{tabular}

$1.02 \%$ (median: 2.60, range: 0.17-4.05 \%) respectively in cesarean delivery (table 2,3). The mean of the CB volume and $\mathrm{CD}_{34}+$ cells concentration were significantly higher in cesarean delivery than in normal vaginal delivery $(\mathrm{p}<0.01)$.

The mean of the $\mathrm{CB}$ volume and $\mathrm{CD}_{34}+$ cells concentration were significantly higher in heavier birth weight of the baby than in normal birth weight of the baby $(p<0.01)$. Baby sex has no effect on total volume of cord blood collection and CD34+ cells concentration.

The mean of the total CD34+ cells concentration was $0.42 \pm 0.44 \%$ (median - 0.22, range - 0.02-2.16\%) for the group of $50-100 \mathrm{ml}$ of total volume of cord blood collection. The mean of the total $\mathrm{CD}_{34+}$ cells concentration was $2.41 \pm 0.99 \%$ (median - 2.17, range 0.16-4.02 \%) for the group of 101-16o ml of total volume of cord blood collection (table 2). The CD34+ cells concentration was higher in higher volume of cord blood collection. The CD34+ cells concentration was positively correlated with higher volume of cord blood collection $(\mathrm{p}<0.01)$.

\section{DISCUSSION}

Umbilical cord blood has been recently considered as an alternative source of hematopoietic progenitor cells for clinical application [11]. The main difference between cord blood and bone marrow is the smaller number of cells obtained in the cord blood product. As a result, until now, cord blood has been used primarily for children. Some ways to resolve this problem consist of screening and selection of proper cord blood donors before collection, choosing the best methods for collection, increasing the recovery rate of cord blood processing and ex vivo expansion of cord blood [12].
Table 2: Descriptive Statistics of the cord blood derived CD34+ cells concentration in different group $(n=500)$.

\begin{tabular}{llll}
\hline Characteristics & \multicolumn{3}{c}{ CD34+ cell concentration (\%) } \\
\hline & Mean \pm SD & Median & Range \\
\hline $\begin{array}{l}\text { Mode of delivery } \\
\text { Normal vaginal }\end{array}$ & $0.412 \pm 0.42$ & 0.200 & $0.02-1.98$ \\
delivery & & & \\
Caesarian & $2.42 \pm 1.02$ & 2.60 & $0.17-4.05$ \\
delivery & & & \\
Birth weight (gram) & & & \\
1800-2500 & $0.40 \pm 0.44$ & 0.195 & $0.02-2.41$ \\
2600-3900 & $2.35 \pm 0.95$ & 2.15 & $0.17-4.05$ \\
$\begin{array}{l}\text { Total volume collection } \\
\text { (ml) }\end{array}$ & & & \\
$50-100$ & $0.42 \pm 0.44$ & 0.22 & $0.02-2.16$ \\
101-160 & $2.41 \pm 0.99$ & 2.17 & $0.16-4.02$ \\
\hline
\end{tabular}

Table 3: Descriptive Statistics of the total volume of cord blood collection in different group $(n=500)$.

\begin{tabular}{llll}
\hline Characteristics & \multicolumn{2}{c}{ Total volume collection (ml) } \\
\hline & Mean \pm SD & Median & Range \\
Mode of delivery & & & \\
Normal vaginal delivery & $79.47 \pm 13.04$ & 80 & $70-120$ \\
Caesarian delivery & $137.22 \pm 17.80$ & 140 & $100-140$ \\
Birth weight (gram) & & & \\
$1800-2500$ & $92.50 \pm 12.36$ & 95 & $60-125$ \\
$2600-3900$ & $144.05 \pm 13.36$ & 145 & $100-160$ \\
\hline
\end{tabular}

The expansion of cord blood cells is being studied as a method of increasing the number of progenitor cells, but no conclusive data is available, thus only the improvement of collection and selection of proper cord blood unit represent an effective strategy for improving the efficacy and reducing the costs of this therapy. The success of UCB cells transplantation is largely related to the number of TNC and $\mathrm{CD}_{34}+$ cells. The quality of Cord blood unit depends on its content in total nucleated cells (TNC), colony forming cells (CFC) and CD34+ cells [13].

Furthermore, a number of factors have been described that may influence the total volume collected, quantification of UCB CD34+ cells, and TNC and that may account for the variations in the reported results.

Some studies shows that caesarian deliveries provides collection of a higher volume of cord blood than vaginal deliveries. They also stated that higher cord blood volume is correlated with high concentration of 
CD34+ cells [14]. Previous studies reported that the mode of delivery has no impact on CB yield [15]. It has been reported that volume, as expected, is clearly associated with higher cell counts, CFU-GM and CD34+ cell counts [16]. In our study, Cord Blood volume was significantly higher in CDs than in VDs $(p<0.01)$. Similarly, CD34+cell count was also higher in CDs than in VDs $(\mathrm{p}<0.01)$.

Other studies reported that there was a positive correlation between volume of collected umbilical cord blood and newborn weight as well as a positive correlation was found between newborn weight with CD34+ cells and total nucleated cell count [17].

In our study, there was a positive correlation between volume of collected UCB and higher birth weight of the baby, $(p<0.01)$ which can thus result in an increase in the absolute number of $\mathrm{CD}_{34}+$ cells. Other studies showed that no association was detected between baby sex with total volume of cord blood collected. It has been also shows that factor like sex can affect the concentration of CD34+ cells [18]. In our analysis no connection was detected between baby sex with total volume of cord blood collected, CD34+ cell count and Total nucleated count.

Some studies shows that, as the volume of collected $\mathrm{UCB}$ directly affects the quantity of $\mathrm{CD} 34+$ cells per micro liter of blood and possibly the quantity of total nucleated cells. A significant positive correlation was found between the relative number of $\mathrm{CD} 34+/ \mathrm{CD} 117-$ cells and the volume of UCB, the CD34+ cells. In another study volume, as expected, is clearly associated with higher CD34+ cells counts. Many cord blood banks have set a lower limit of acceptable volume, such as 4060 cc without anticoagulant [19]. Cord blood can be collected either before or after the delivery of the placenta; in their programmed cord blood is collected before delivery of the placenta [20]. Early cord blood clamping may increase the volume of collection, but raises ethical concerns, and is generally practiced [21, 22]. In a study, where 1,200 donors were evaluated, it was observed that high volume samples were correlated with high doses of TNCs, CD34+ cells and colony forming units of granulocytes and macrophages (CFUGM) [23]. In our analysis we also find that there was a significant positive correlation between the total volume of cord blood collection with cord blood derived CD34+ cells concentration.

\section{CONCLUSION}

In conclusion, total volume of cord blood and CD34+ cells concentration were positively correlated with cesarean delivery and higher birth weight of the baby. Baby sex have no effect on cord blood volume and CD34+ cells concentration. The volume of collected umbilical cord blood showed positively correlation with CD34+ cells concentration.

\section{Author Contributions}

Tulika Chandra - Substantial contributions to conception and design, Acquisition of data, Analysis and interpretation of data, Drafting the article, Revising it critically for important intellectual content, Final approval of the version to be published

Sheeba Afreen - Substantial contributions to conception and design, Acquisition of data, Analysis and interpretation of data, Drafting the article, Revising it critically for important intellectual content, Final approval of the version to be published

Ashutosh Kumar - Substantial contributions to conception and design, Acquisition of data, Analysis and interpretation of data, Drafting the article, Revising it critically for important intellectual content, Final approval of the version to be published

Uma Singh - Substantial contributions to conception and design, Acquisition of data, Analysis and interpretation of data, Drafting the article, Revising it critically for important intellectual content, Final approval of the version to be published

\section{Guarantor}

The corresponding author is the guarantor of submission.

\section{Conflict of Interest}

The authors have no conflicts of interest

\section{Copyright}

(C) Tulika Chandra et al. 2011; This article is distributed under the terms of Creative Commons attribution 3.0 License which permits unrestricted use, distribution and reproduction in any means provided the original authors and original publisher are properly credited. (Please see www.ijbti.com/copyright-policy.php for more information.)

\section{REFERENCES}

1. Cairo MS, Wagner JE. Placental and/or umbilical cord blood: an alternative source of hematopoietic stem cells for transplantation. Blood 1997;90:466578.

2. Gluckman E. Current status of umbilical cord blood hematopoietic stem cell transplantation. Exp Hematol 2000;28:1197-1205.

3. Wadlow RC, Porter DL. Umbilical cord blood transplantation: where do we stand. Biol Blood Marrow Transplant 2002;8:637-47.

4. Gluckman E, Broxmeyer HE, Auerbach $\mathrm{AD}$, et al. Hematopoitic reconstitution in a patient with Fanconi anemia by means of umbilical cord blood from an HLA-identical sibling. $N$ Engl $J$ Med 1989;321:1174-8.

5. Newberger P, Queseenbery P. Umbilical cord blood as a new and promising source of unrelated- donor hematopoietic stem cells for transplantation. I curr opin pediat 1996;8:29-32. 
6. Rubinstein P, Carrier C, Scaradavou A et al. Outcomes among 562 recipients of placental blood transplants from unrelated donors. N Engl J Med 1998;339:1565-77.

7. Cohen S, Dominguez E, Lowd ell M, Madrigal J. The immunological properties of cord blood overview of current research presented at 2nd Euro cord workshop. Bone marrow transplant 1998;22(suppl 1):522-5.

8. Varadi G, Elchalal U, Brautbar C, Nagler A. Human umbilical cord blood for hematopoietic progenitor cells transplantation. J Leuk Lymphoma 1995;20:5158.

9. Sirchia G, Rebulla P, Leachy L. Implementation of a quality system (iso 9000 series) for placental blood bnking. J Hematother 1998;7:19-35.

10. Gluckman E, Rocha V, Boyer-Chammard A, Locatelli F, Arcese W, Pasquini R. Outcome of cord-blood transplantation from related and unrelated donors. N Engl J Med 1997;337:373-81.

11. Thompson C. umbilical cords. turning garbage into clinical gold. Science 1995;268:805-6.

12. Mohyeddin Bonab M, Goliaei Z, Alimoghaddam K, Ghavamzadeh. Evaluation of the Affect of Maternal and Neonatal Factors on Cord Blood Parameters. Heamatology, Oncology \& BMT Research center 2004;1(1):20-24.

13. Wagner JE, Kurtzberg J. Cord blood stem cells. CurrOpin Hematol 1997;4:413-8.

14. Yamada T, Okamoto Y, Kasamatsu H, Horie Y, Yamashita N, Matsumoto K. Factors affecting the volume of umbilical cord blood collections. Acta Obstet Gynecol Scand 2000;79:830-3.

15. Lim FT, van Winsen L, Willemze R, Kanhai HH, Falkenburg $\mathrm{JH}$. Influence of delivery on numbers of leukocytes, leukocyte subpopulations, and hematopoietic progenitor cells in human umbilical cord blood. Blood Cells 1994;20:547-59.

16. Ballen KK, Wilson M, Wuu J et al. Bigger is better maternal and neonatal predictors of hematopoietic potential of umbilical cord blood units. Bone marrow transplant 2001;27(1):7-14.

17. Raquel Canabarro, Heloísa Sporleder, Thaís Gomes, Geancarlo Zanatta, Letícia Scribe, Fernando Freitas, Jorge Neumann, and Patricia Pranke. Immunophenotypic evaluation, and physiological and laboratory correlations of hematopoietic stem cells from umbilical cord blood. Biocell 2007;31(3):397-403.

18. Nakagawa R, Watanabe $\mathrm{T}$, Kawano $\mathrm{Y}$, Kanai $\mathrm{S}$, Suzuka H, Kaneko M, et al. . Analysis of maternal and neonatal factors that influence the nucleated and CD34+ cell yield for cord blood banking. Transfusion 2004;44:262-7.

19. Kogler G, Callejas J, Hakenberg P et al. Hematopoietic transplant potential of unrelated cord blood: critical issues. J Hematother 1996; 105-16.

20. Wall DA, Noffsinger JM, Mueckl KA et al. Feasibility of an obstetrician-based cord cell transplant. J Maternal-Fetal Med 1997;6: 320-3.

21. Bertolini F, Lazzari L, Corsini C et al. Cord blood banking for stem cell transplant. Inter $\mathrm{J}$ Artificial Org 1993;16:111-2.

22. Sugarman J, Reisner EG, Kurtzberg J. Ethical aspects of banking placental blood for transplantation. JAMA 1995;274:1783-5.
23. Bradley MB, Cairo MS 2005. Cord Blood Immunology and Stem Cell Transplantation. Hum Immunol 2005;66:431-46. 